\title{
THE USE OF INTERNATIONAL TAX PLANNING IN SUBSIDIARIES FROM THE FINANCIAL AND ICT SECTORS IN THE CZECH REPUBLIC
}

\author{
Vít Jedlička'
}

1 University of Pardubice, Faculty of Economics and Administration, Institute of Business Economics and Management, Czech Republic, ORCID: 0000-0002-8328-2351, vit.jedlicka@upce.cz.

\begin{abstract}
Tax avoidance is an important element of management in the global economy. Managers use tax havens for reducing a company's effective tax rate. The most common practices in international tax planning can be divided into three groups: loans and their related interest, royalties, and transfer pricing. The aim of this article is to find the determinants of the tax burden faced by foreign-owned subsidiaries. Therefore, a model was created for the tax burden, focusing on the special position of subsidiaries within international tax planning. For this purpose, taxes/outcomes was established as a new dependent variable. The panel data used include Czech companies that are owned by parent companies located in other EU countries. The model distinguishes EU tax havens from regular member states; sector dummy variables are also included. The regression model that was created did not confirm the assumed dependencies. Rather, it indicated other important determinants: profitability, the share of intangible assets, size, and the dummy variable for the ICT sector. Based on the regression results, the independent variables connected with known tax planning schemes have relatively low importance. The significance of these results can be seen in the subsequent conclusions. First of all, there is no difference between the subsidiaries' tax burdens based on the parent company's location. Corporations use international tax planning whether or not they are owned from a tax haven. The second significant conclusion indicates the importance of certain sectors and their attributes concerning the tax burden. Companies from the ICT sector are linked to a lower tax burden. On the other hand, the dependencies within the financial sector are not statistically significant. From the perspective of further research, it would be constructive to incorporate the subsidiary's position within the group.
\end{abstract}

Keywords: Tax planning, tax burden, tax havens, panel data, regression.

JEL Classification: F23, H25, H26.

APA Style Citation: Jedlička, V. (2021). The Use of International Tax Planning in Subsidiaries from the Financial and ICT Sectors in the Czech Republic. E\&M Economics and Management, 24(1), 182-196. https://doi.org/10.15240/tul/001/2021-1-012

\section{Introduction}

Managers seek every opportunity to increase the profitability of their company's investments. They also encounter various types of costs from the managerial perspective, these include paid taxes. Therefore, the management at multinational corporations takes advantage of the global digital economy and tries to plan tax liabilities in order to minimize them. Ignoring the opportunity to avoid taxes can result in a less competitive position. Tax planning has become an important tool for achieving better financial results. Within the global economy, the international aspect of tax planning is a key factor for multinational corporation management.

The importance of tax burdens can also be seen in decision making on where to invest. 
Lower tax burdens can increase an investment's profitability; therefore, managers incorporate rating tax legislation into their decision-making process for investment. Evaluation includes not only the laws in the intended target country but also the domestic country's tax legislation and tax treaties. International tax planning is based on cross-border payments, and their taxation should be considered previous to investment. Governments respond to managers' demands and alter tax legislation in order to attract investments, which causes tax competition to arise (Wiebe, 2011). Tax competition results in tax havens, whose aim is to attract multinational companies to achieve higher tax revenues, gain extensive investment, or create more jobs.

Tax havens' effect on the tax burden of multinational corporations has been demonstrated by a number of studies (Markle \& Shackelford, 2014; Schulte et al., 2017; Davies et al., 2018). However, all recent studies have assessed the tax burden from the perspective of an entire group or parent company. The question then arises as to what role the subsidiaries play within tax planning schemes. First, subsidiaries may be established in a tax haven only for tax purposes (a common view), or they may be operating companies within the group that have the company in a tax haven as their parent company (this reverse scheme can also achieve a tax advantage). There are many companies owned from abroad in the Czech Republic, and there are frequent debates about the use of tax planning and tax revenue losses (Moravec et al., 2019). Therefore, it is important to study subsidiaries' position within international tax planning, even if they do not reside in a tax haven. How a specific non-tax-haven country with many foreign-owned companies is positioned regarding tax planning was also shown in the first studies focused on Czech companies (Janský \& Kokeš, 2015; Janský, 2017). The use of tax havens by Czech companies shows some anomalies compared to the results of studies involving companies from several countries around the world.

The aim of this paper is to find the determinants of the tax burden faced by subsidiaries in a non-tax-haven country. The specific positioning of the operating subsidiaries has not been included in recent studies, and it can be assumed that their tax burden may show some determinants other than the usual ones.

The following section deals with the current state of knowledge on the outlined topic. The next section of the paper describes the methods used, followed by a presentation of the model's results. In the subsequent section, the concrete results are discussed in the context of the current state of knowledge, and recommendations for further research are outlined. Conclusions based on the previous sections follow.

\section{Theoretical Background}

Tax planning can be defined as any type of activity with the special purpose of reducing tax liability (OECD, 2020a). There are three basic methods used in international tax planning schemes: royalties (connected with the intellectual property), interest payments (intra-group loans are key), and transfer pricing (European Commission, 2016; Auerbach et al., 2017). The study of one concrete multinational company (Cadbury Schweppes) demonstrated the inclination of managers to use transfer pricing more than internal debt (Schenkelberg, 2020). The greater importance of transfer pricing - in addition to the use of licenses and royalties - is also shown in a study by Heckemeyer and Overesch (2017). Where governments are concerned, transfer pricing is approximately $1 \%$ of the total French collected taxes (Davies et al., 2018). Naturally, not all multinational corporations use transfer pricing in order to avoid taxes. Klassen et al. (2017) show that there are differences between managers' approaches to transfer pricing. It has also been proved that IP assets play a significant role in international tax planning (Arcalean, 2017). Because of their mobility, intangible assets are a suitable instrument to adopt as part of specific tax planning schemes (Griffith et al., 2014). Karkinsky and Riedel (2012) demonstrate the use of this mobility, concluding that patents within a group are placed in countries with a lower tax burden. The negative effect of intangible assets on effective tax rates was also verified by Klassen et al. (2017). The presence of an IP box even increases the advantage of using intangible assets for tax planning to such an extent that effective average tax rates can achieve negative values (Evers et al., 2015). Although the first two methods are used more commonly, intra-group loans are also included in managerial practice. German multinational companies use internal debt financing when at least one of their subsidiaries is located in a country with a low tax burden (Buettner \& 
Wamser, 2013). Naturally, the tax planning issue also has another side. Certain managers, for whom reputation is important, do not implement tax planning (Graham et al., 2014), because public pressure is an important factor, especially for widely known multinationals (Campbell \& Helleloid, 2016).

Concerning international organizations, there is a tendency towards minimizing the opportunities for international tax planning. The OECD (2020b) uses its BEPS (Base Erosion and Profit Shifting) project, and the European Commission (2020) investigates tax planning cases, because a bilateral agreement between a company and the government can result in an unauthorized subsidy. The attitudes of the OECD and the European Commission are characterized by an emphasis on the role of countries - more precisely governments - as bearing the responsibility for the negative impact of international tax planning.

These two organizations have come up with their own lists of tax havens, although both initiatives have some gaps. The OECD's list (2020c) is now empty, and the one by the European Commission (2018a) only deals with non-member countries. However, tax havens do exist in the European Union, which has been confirmed by the European Commission's own investigation as well as by other studies (Gravelle, 2015; Berkhout, 2016; Chardonnet \& Langerock, 2017). These studies confirm the importance of EU countries like the Netherlands or Luxembourg in international tax planning. From the perspective of tax planning research, it is crucial to define the set of tax havens correctly. EU tax havens can be seen as a gateway for connecting companies operating in other EU countries and tax havens outside the EU; in some cases, the tax planning scheme does not require the presence of tax havens outside the EU (European Commission, 2016).

The importance of companies having an international aspect was shown by Rego (2003) and Desai et al. (2006); large US companies with higher levels of internationalization use tax havens more than other firms. Not only was the international aspect studied, but the actual effects of tax haven connections were also given substantial attention. Schulte et al. (2017) illustrated the importance of the number of subsidiaries located in tax havens. Groups with more subsidiaries in tax havens tend to use international tax planning to a larger extent. Integrating a subsidiary located in a tax haven reduces the group's tax burden, especially when it is this type of company's first establishment (Markle \& Shackelford, 2014). Similar results were also presented in a study of US companies by Dyreng and Lindsey (2009). Based on known tax planning schemes, EU tax havens are the most important from the perspective of the operating subsidiaries (e.g., companies in the Czech Republic or Slovakia), because the operating companies are directly connected to them.

Consequently, several limitations have emerged in connection with the current studies. The approach taken by most researchers consists of assessing dependencies within a large dataset covering several countries from different parts of the world (Dischinger et al., 2014; Markle \& Shackelford, 2014; Delgado et al., 2014). On the other hand, there are also studies that show the differences between countries regarding tax planning activities. Yoo and Lee (2019) demonstrate the importance of national culture and its characteristics, such as individualism. Jones and Temouri (2016) distinguish countries by type of economy, with the conclusion that multinational corporations originally from liberal market economies (e.g., the USA, the United Kingdom, or Australia) use tax havens more than companies from coordinated market economies (Germany, Sweden, or Austria). Studies focusing only on the Czech Republic also confirm that the results from worldwide studies cannot be transferred; the conclusions for Czech companies are not as clear or as significant (Janský \& Kokeš, 2015, 2016).

The latest development in international tax planning is connected to activities in certain sectors. The advancement of information technology is also helping international tax planning evolve further. This can be evidenced by activities of the OECD (2020d), the European Commission (2018b), and individual countries (Asen, 2019) that caused new taxes on digital services to be introduced. Jones and Temouri (2016) discovered that high-tech companies use tax havens for the purposes of tax avoidance more than companies from other types of sectors. These results are in line with a study by Higgins et al. (2015), which shows that innovative companies are pioneers in international tax planning. On the other hand, 
it is not only the digital sector that is known for having a lower tax burden compared to other sectors (European Commission, 2017); financial institutions also often use international tax planning (Gallemore et al., 2019) in connection with tax havens (Aubry \& Dauphin, 2017; Bouvatier et al., 2017; Murphy, 2015). This information about sectors has become an integral part of tax planning analysis (Delgado et al., 2014; Sorbe \& Johansson, 2017); certain specific sector attributes impact the tax burden. How tax havens are used also differs across sectors for German multinationals (Gumpert et al., 2016). From the perspective of investment decision making, companies from sectors with a tendency to use tax planning are not affected by the tax burden of the new investment (Hong \& Smart, 2010; Sorbe \& Johansson, 2017). Such companies have the ability to minimize tax liabilities using the schemes that have been already established.

This paper provides a different perspective on tax planning, because it is focused only on subsidiaries linked to foreign owners. The model in the following section was developed based on these assumptions. The following hypotheses were established based on the theoretical background:

$H_{1}$ : A parent company located in a tax haven decreases a subsidiary's tax burden.

$\mathrm{H}_{2}$ : The level of indebtedness decreases a company's tax burden.

$\mathrm{H}_{3}$ : The ratio of intangible assets to total assets decreases a company's tax burden.

When analyzing current research, it was obvious that there were some differences between sectors in terms of tax planning. Current studies have provided conclusions supporting the idea that certain sectors have better opportunities to use international tax planning and that these companies thus have a lower effective tax burden (e.g., the ICT or financial sectors). However, there is as yet no comparison of the sectors that use tax havens. Naturally, there should be differences in how sectors use tax havens, because they have different assets and capital structures; additionally, their core businesses are completely different. It is also worth mentioning that there are differences inside each sector. For these reasons, this paper is focused on the two sectors that are usually presented as having strong tendencies to use international tax planning: the ICT sector and the financial sector.

\section{Data and Research Methodology}

Because the Czech Republic's position concerning international tax planning is distinct, the data used covers only Czech companies. Because a company's degree of internationalization is an important aspect (otherwise international tax planning is not possible), further analysis covers the component of the Czech companies that are owned from abroad, specifically from EU countries. For better results, panels of data from financial statements for the years 2013-2016 are used; these were collected from Justice.cz (2018). Within studied period, 340 companies from ICT sector and 123 from financial sector were in the Czech Republic. Sectors are based on the classification CZ-NACE: ICT sector corresponds to section $\mathrm{J}$ and financial sector includes companies from section $\mathrm{K}$. Tab. 1 presents the basic data concerning sectors. It is worth mentioning that the dataset contains only companies with relevant economic activity, i.e., non-zero outcomes. The aim was to examine a balanced panel and therefore companies that were not active for all four years have been excluded. The extreme values have also been dropped from the dataset. As extreme values, e.g., negative values of intangible assets were considered. This might be a case of sale of part of the company in which revaluation differences arise. In some other cases, companies reported other parts of assets in negative values. On the other hand, when the value corresponded to a logical framework it was kept in the dataset. This study focuses on tax planning and some of the outliers can explain how the tax planning of Czech companies works. Overall, there were removed 125 companies in ICT sector and 85 companies in financial sector. Especially in the financial sector, the number of removed companies is high. It shows that companies in financial sector has a higher degree of instability. More than half of the removed financial companies had zero outcomes. The panel data analysis was performed according to Greene (2012) and Wooldridge (2013).

The purpose of the model was to find determinants of the tax burden under Czech conditions from the perspective of subsidiaries of foreign multinationals; it is based on the approach presented by Jedlička (2019). 
Tab. 1: Basic information about the dataset

\begin{tabular}{l|c|c|c}
\multicolumn{1}{c|}{ Sector } & ICT & Financial & Overall \\
\hline Number of companies & 215 & 38 & 253 \\
\hline \% owners from tax havens & $26.98 \%$ & $28.95 \%$ & $27.27 \%$ \\
\hline
\end{tabular}

Source: own

Regarding the fact that panel data was obtained, panel regression was used as the standard model. Panel regression has been used by several researchers, but this paper's approach is different, especially in the case of the dependent variable. Because this study aims to assess the position of Czech companies as subsidiaries owned from different countries, the tax burden model needed to be customized to meet this requirement. The model is based on the assumption that a particular company is part of an international tax planning structure, and its tax liability is therefore affected by tax planning. Because the usual effective tax rate is based on profits, which are also affected by tax planning, this variable is not an option. The goal was to find a variable for which tax planning affects only tax liability. Other possibilities, e.g., the ratio of paid taxes to total assets, also have the problem that the denominator is dependent on the tax planning itself. Some of the tax planning schemes also affect the size of total assets, making the given ratio not suitable as a dependent variable. It is necessary to select a variable such that the denominator has no connection with international tax planning, with the effect of tax planning being concentrated exclusively in the component of paid taxes. This model offers the ratio of taxes to outcomes as a new dependent variable. Outcomes include sales of own products and services, activation and changes in inventories of own production. Outcomes are not affected by tax planning when it is assumed that the studied subsidiaries are located in a non-tax-haven country. Moreover, outcomes are the most suitable way to express the real economic activity of the operating subsidiaries. The rest of the model's construction is based on current knowledge. The regression uses the assumptions for panel data regression and is presented in Formula (1):

$$
\begin{aligned}
& \text { TXoutcomes }=\beta_{0}+\beta_{1} R_{0 A_{i t}}+ \\
& +\beta_{2} I A_{i t}+\beta_{3} S I Z E_{i t}+\beta_{4} I N D E B T_{i t}+ \\
& +\beta_{5} I N V_{i t}+\beta_{6} T H_{i}+a_{i}+u_{i t}
\end{aligned}
$$

There is an important assumption about why taxes divided by the outcomes linked to operating subsidiaries is able to reflect the tax planning. First of all, when a company uses tax planning, all tax planning activities take place between achieving the outcomes and paying taxes. Naturally, all known tax planning schemes do not affect the operating subsidiaries' outcomes, because these outcomes are newly created value. In contrast, profit can be affected by several tax planning schemes; therefore, it can be said that outcome taxation better expresses the real tax burden.

In addition to Formula (1), $a$ represents the unobserved individual effect and $u$ represents the model's error. The variables are described in Tab. 2, which also presents their basic descriptive statistics. The median of $I A$ is 0 and it means that most companies have no intangible assets. Similar situation has appeared also for the variable $I N V$. Companies from ICT and financial sectors do not need as much inventory due to the characteristics of these industries.

Furthermore, it was also crucial to establish the group of EU tax havens. This part of the study is based on current research (Berkhout, 2016; Chardonnet \& Langerock, 2017; Jedlička, 2019). For the purposes of this study, Cyprus, Ireland, Luxembourg, Malta, and the Netherlands are considered EU tax havens. The data contains only the information about whether the company has an owner from a tax haven. Therefore, this variable remains unchanged over all periods.

Because the dataset can be considered panel data, panel regression was assumed for the model. Three types of regression were used: pooled OLS, regression with fixed effects, and regression with random effects. As for the explanatory power of the model, additional statistics tests were also conducted. Another important feature of the model deals with sectors. Because this paper intends to 


\section{Tab. 2: Variables and their descriptive statistics}

\begin{tabular}{l|l|c|c|c|c|c}
\multicolumn{1}{c|}{ Variable } & \multicolumn{1}{|c|}{ Description } & Mean & Median & St. deviation & Minimum & Maximum \\
\hline TXoutcomes & $\begin{array}{l}\text { Paid taxes divided } \\
\text { by the outcomes }\end{array}$ & 0.0257 & 0.0114 & 0.0505 & 0 & 0.7566 \\
\hline ROA & $\begin{array}{l}\text { Return on assets } \\
\text { calculated using EBIT }\end{array}$ & 0.0575 & 0.0830 & 0.6354 & -9.9900 & 1.9800 \\
\hline IA & $\begin{array}{l}\text { Share of intangible } \\
\text { assets in total assets }\end{array}$ & 0.0305 & 0 & 0.1040 & 0 & 0.9669 \\
\hline SIZE & $\begin{array}{l}\text { Natural logarithm } \\
\text { of total assets }\end{array}$ & 10.1985 & 10.0791 & 2.5999 & 2.4849 & 17.4888 \\
\hline INDEBT & $\begin{array}{l}\text { Liabilities divided } \\
\text { by total assets }\end{array}$ & 0.6623 & 0.4998 & 1.0234 & 0 & 16.0232 \\
\hline INV & $\begin{array}{l}\text { Share of inventories } \\
\text { in total assets }\end{array}$ & 0.0265 & 0 & 0.0951 & 0 & 0.8506 \\
\hline TH & Dummy variable which express the presence of the owner in tax haven.
\end{tabular}

determine the impact of sectors - which is constant over time - panel regression with random effects was also conducted, regardless of the additional tests' results (Wooldridge, 2013). The tax haven dummy variable is also similar in nature, so panel regression with random effects is also important for discovering the effects of the specific owner's location.

\section{Results and Discussion}

All results are based on the author's own calculations using the software Gretl. Tab. 3 presents the results of the OLS regression with the full dataset. The Breusch-Pagan test statistic demonstrates whether OLS regression is an appropriate type of regression. Regression with random effects is a more suitable model than OLS regression because

\section{Tab. 3: OLS regression}

\begin{tabular}{l|c|c|c|c}
\multicolumn{1}{c|}{ Variable } & Coefficient & Std. error & T-share & P-value \\
\hline Constant & 0.0282622 & 0.00937198 & 3.016 & $0.0026^{* *+*}$ \\
\hline ROA & 0.00929143 & 0.00257791 & 3.604 & $0.0003^{*+*}$ \\
\hline IA & -0.0232054 & 0.0146480 & -1.584 & 0.1135 \\
\hline SIZE & 0.00245507 & 0.000680328 & 3.609 & $0.0003^{* * *}$ \\
\hline INDEBT & -0.00180926 & 0.00160070 & -1.130 & 0.2586 \\
\hline INV & 0.0111627 & 0.0161319 & 0.6920 & 0.4891 \\
\hline TH & -0.00590722 & 0.00358891 & -1.646 & 0.1001 \\
\hline ICT & -0.0293633 & 0.00471375 & -6.229 & $6.88 \mathrm{e}^{-10^{* * * *}}$
\end{tabular}

Breusch-Pagan test statistic: $L M=552.89$ with $p$-value $=2.95966 \mathrm{e}^{-122}$

Hausman test statistic: $\mathrm{H}=12.16$ with $\mathrm{p}$-value $=0.0326598$

Note: ${ }^{* *}$ statistically significant at a level of $0.01 ;{ }^{* *}$ statistically significant at a level of $0.05 ;{ }^{*}$ statistically significant at a level of 0.1 . 
of the low p-value. The second test (the Hausman test) provides information about the suitability of regression with random effects in comparison with fixed effects. At a 0.05 level of significance, the Hausman test preferred fixed effects regression. At the same time, this paper focuses on variables that are constant across all time periods, therefore regression with random effects was also used.
As to the specific results, the OLS regression indicated three important variables - ROA, SIZE, and the ICT sector dummy variable. However, both the other models provided more relevant results. Therefore, Tab. 4 shows the results of the panel regression with fixed effects. Two important assumptions must be mentioned in conjunction with this method: constant variables have been excluded and

\section{Tab. 4: Panel regression with fixed effects}

\begin{tabular}{l|c|c|c|c}
\multicolumn{1}{c|}{ Variable } & Coefficient & Std. error & T-share & P-value \\
\hline Constant & -0.0283502 & 0.0278581 & -1.018 & 0.3092 \\
\hline ROA & 0.00275833 & 0.00195623 & 1.410 & 0.1589 \\
\hline IA & -0.0586059 & 0.0169774 & -3.452 & $0.0006^{* * *}$ \\
\hline SIZE & 0.00536936 & 0.00272712 & 1.969 & $0.0493^{* *}$ \\
\hline INDEBT & -0.000962872 & 0.00207156 & -0.4648 & 0.6422 \\
\hline INV & -0.00533159 & 0.0209439 & -0.2546 & 0.7991 \\
\hline Time dummy 2 & 0.00214280 & 0.00269838 & 0.7941 & 0.4274 \\
\hline Time dummy 3 & 0.00168664 & 0.00275520 & 0.6122 & 0.5406 \\
\hline Time dummy 4 & 0.00280458 & 0.00283992 & 0.9876 & 0.3237 \\
\hline
\end{tabular}

LSDV R-squared $=0.741227$

Within R-squared $=0.037476$

Source: own

Note: ${ }^{* * *}$ statistically significant at a level of 0.01 ; ${ }^{* *}$ statistically significant at a level of 0.05 ; *statistically significant at a level of 0.1 .

time dummies have been added to the model.

Tab. 4 shows the results of the panel regression with fixed effects. This model best meets the requirements from the perspective of reliability. It reveals two important variables at the 0.05 level of significance: the share of intangible assets (a negative effect) and the size of the company (a positive effect). The variables, which are constant over time, are included within the fixed effects.

Although this model does not provide any information connected to the constant variables, the importance of intangible assets could also indicate the differences between the financial and the ICT sector. However, the variant with random effects was also conducted to better identify the significance of the other variables.

The results of the panel regression with random effects are presented in Tab. 5. This model shows the significance not only of the company's size and its intangible assets but also of its profitability and the ICT sector dummy variable. The significance of belonging to a specific sector can be seen here as an especially important result. The random effects model, like the OLS one, did not indicate the parent company's location as important.

Neither panel regression revealed any time effects. Overall, all three models demonstrated the significance of company size. In other aspects, the models did have certain differences. However, the importance of intangible assets and the ICT sector dummy was indicated in all models. From the perspective of profitability, the conclusions were not as strong, because the best model (with fixed effects) did not recognize it as a significant independent variable.

Previous results have shown significant differences between the two sectors studied. The ICT sector was revealed to have the 


\section{Tab. 5: Panel regression with random effects}

\begin{tabular}{l|c|c|c|c}
\multicolumn{1}{c|}{ Variable } & Coefficient & Std. error & $\mathbf{Z}$ & P-value \\
\hline Constant & 0.0198454 & 0.0147637 & 1.344 & 0.1789 \\
\hline ROA & 0.00397061 & 0.0018894 & 2.102 & $0.0356^{* *}$ \\
\hline IA & -0.0465778 & 0.0147134 & -3.166 & $0.0015^{* * *}$ \\
\hline SIZE & 0.00299253 & 0.00106579 & 2.808 & $0.0050^{* * *}$ \\
\hline INDEBT & -0.00170844 & 0.00167649 & -1.019 & 0.3082 \\
\hline INV & 0.00124161 & 0.0173681 & 0.07149 & 0.9430 \\
\hline TH & -0.00624857 & 0.00600526 & -1.041 & 0.2981 \\
\hline ICT & -0.0269972 & 0.00779359 & -3.464 & $0.0005^{* * *}$ \\
\hline Time dummy 2 & 0.00265878 & 0.00267439 & 0.9942 & 0.3201 \\
\hline Time dummy 3 & 0.00244042 & 0.00268375 & 0.9093 & 0.3632 \\
\hline Time dummy 4 & 0.00383191 & 0.00271118 & 1.413 & 0.1575 \\
\hline
\end{tabular}

Source: own

Note: ${ }^{* * *}$ statistically significant at a level of $0.01 ;{ }^{* *}$ statistically significant at a level of 0.05 ; *statistically significant at a level of 0.1 .

lower tax burden. In order to identify additional differences, the same three models were used again but with data from each sector individually. These models focused on the differences in the tax burden between sectors and show how companies from the two selected sectors use tax planning.
Tab. 6 presents the OLS regressions for both the ICT and financial sectors. The coefficients of the individual variables as well as their significance differ. As to the ICT sector, profitability, intangible assets, and size are the main drivers of the tax burden. On the other hand, for the financial sector, the only variable

\section{Tab. 6: OLS regression: ICT vs. the financial sector}

\begin{tabular}{|c|c|c|c|c|c|c|c|c|}
\hline \multirow{2}{*}{ Variable } & \multicolumn{4}{|c|}{ ICT } & \multicolumn{4}{|c|}{ Financial sector } \\
\hline & Coefficient & Std. error & T-share & P-value & Coefficient & Std. error & T-share & P-value \\
\hline Constant & 0.003508 & 0.006066 & 0.5783 & 0.5632 & 0.025684 & 0.043917 & 0.5848 & 0.5596 \\
\hline ROA & 0.008252 & 0.002154 & 3.831 & $0.0001^{*+*}$ & 0.041980 & 0.024470 & 1.716 & $0.0884^{*}$ \\
\hline IA & -0.024695 & 0.012045 & -2.050 & $0.0406^{* *}$ & -0.243222 & 0.422459 & -0.5757 & 0.5657 \\
\hline SIZE & 0.001834 & 0.000622 & 2.947 & $0.0033^{\cdots *}$ & 0.003054 & 0.003047 & 1.002 & 0.3179 \\
\hline INDEBT & -0.002108 & 0.001354 & -1.557 & 0.1198 & 0.001822 & 0.012323 & 0.1478 & 0.8827 \\
\hline INV & 0.011188 & 0.013239 & 0.8450 & 0.3983 & -3.47228 & 8.74177 & -0.3972 & 0.6918 \\
\hline $\mathrm{TH}$ & 0.000599 & 0.003314 & 0.1806 & 0.8567 & -0.033604 & 0.014989 & -2.242 & $0.0265^{* *}$ \\
\hline Added tests & \multicolumn{4}{|c|}{$\begin{array}{l}\text { Breusch-Pagan test statistic: } \\
\text { LM }=497.728 \text { with } p \text {-value }=2.96742 \mathrm{e}^{-110} \\
\text { Hausman test statistic: } \\
H=17.2453 \text { with } p \text {-value }=0.00405734\end{array}$} & \multicolumn{4}{|c|}{$\begin{array}{l}\text { Breusch-Pagan test statistic: } \\
\text { LM }=68.3805 \text { with } p \text {-value }=1.34804 \mathrm{e}^{-16} \\
\text { Hausman test statistic: } \\
\mathrm{H}=3.21523 \text { with } p \text {-value }=0.666843\end{array}$} \\
\hline
\end{tabular}

Note: ***statistically significant at a level of 0.01 ; ${ }^{* *}$ statistically significant at a level of 0.05 ; *statistically significant at a level of 0.1 . 
that is statistically significant at the level of 0.05 is tax havens. Moreover, there are also differences in the additional tests. The BreuschPagan test shows that the type of regression used in these OLS models is not suitable for either sector. On the other hand, the Hausman test favors the fixed effects model for the ICT sector but the random effects model for the financial sector.

Similar to the approach above, panel regression with fixed effects is used with the results presented in Tab. 7. For the ICT sector, the share of intangible assets has a negative effect on the tax burden while size has a positive effect. The results for the financial sector show only one significant variable: the dummy for the last year (2016). It is important to mention that no independent variable used in the model was considered statistically significant for the tax burden in the financial sector. This is also the reason why the additional tests favor the random effects model. This situation indicates that there are other variables not included in this model that are particularly important for the financial sector.

Tab. 8 presents the panel regression with random effects for the ICT and financial sectors. The results are similar to the model with fixed effects with one exception: profitability is also included in the set of variables that are important drivers of the tax burden in the ICT sector at a significance level of 0.05 . As to the financial sector, the results of the model with random effects are overall the same as those for the regression with fixed effects.

Overall, the regressions showed that there are significant differences between the ICT and financial sectors. This is valid not only in terms of their tax burden level but also in terms of the variables that can explain their tax burden. Regarding the ICT sector, the model gave satisfactory results. On the other hand, the same model provided noticeably worse results when used for companies from the financial sector, with none of the predicted variables able to be considered significant. There is only a shift to a higher tax burden in the fourth year.

The individual hypotheses were assessed based on these results. $H_{1}$ was rejected, because there was no regression with higher explanatory power that indicated the tax haven dummy variable was significant. $\mathrm{H}_{2}$ was also rejected. Indebtedness does not have any impact on the tax burden of Czech subsidiaries. On the other hand, $\mathrm{H}_{3}$ was confirmed. Most models demonstrated that the share of intangible assets was a statistically significant variable with a negative impact on a company's tax burden.

Most studies in international tax planning show the importance of a tax haven connection providing tax burden reduction (Markle \&

\section{Tab. 7: Panel regression with fixed effects: ICT vs. the financial sector}

\begin{tabular}{|c|c|c|c|c|c|c|c|c|}
\hline \multirow{2}{*}{ Variable } & \multicolumn{4}{|c|}{ ICT } & \multicolumn{4}{|c|}{ Financial sector } \\
\hline & Coefficient & Std. error & T-share & P-value & Coefficient & Std. error & T-share & P-value \\
\hline Constant & -0.059002 & 0.023544 & -2.506 & $0.0125^{* \prime \prime}$ & 0.161894 & 0.149602 & 1.082 & 0.2816 \\
\hline ROA & 0.002728 & 0.001584 & 1.723 & $0.0854^{*}$ & -0.003102 & 0.019995 & -0.1551 & 0.8770 \\
\hline IA & -0.060315 & 0.013538 & -4.455 & $9.90 \mathrm{e}^{-6^{6 *+}}$ & -0.519161 & 0.704835 & -0.7366 & 0.4630 \\
\hline SIZE & 0.008385 & 0.002416 & 3.470 & $0.0006^{* *}$ & -0.008173 & 0.011486 & -0.7116 & 0.4783 \\
\hline INDEBT & -0.000387 & 0.001696 & -0.2281 & 0.8197 & -0.013281 & 0.015861 & -0.8373 & 0.4043 \\
\hline INV & -0.007236 & 0.016665 & -0.4342 & 0.6643 & 2.01316 & 9.58448 & 0.2100 & 0.8340 \\
\hline Time $d_{3}$ & 0.001393 & 0.002339 & 0.5956 & 0.6643 & 0.003818 & 0.012213 & 0.3126 & 0.7552 \\
\hline Time $d_{2}$ & -0.000682 & 0.002398 & -0.2845 & 0.7761 & 0.012858 & 0.012478 & 1.030 & 0.3052 \\
\hline \multirow[t]{2}{*}{ Time $d_{4}$} & -0.001892 & 0.002475 & -0.7645 & 0.4449 & 0.027747 & 0.012743 & 2.177 & 0.0317 \\
\hline & \multicolumn{4}{|c|}{$\begin{array}{l}\text { LSDV R-squared }=0.742490 \\
\text { Within R-squared }=0.069956\end{array}$} & \multicolumn{4}{|c|}{$\begin{array}{l}\text { LSDV R-squared }=0.712428 \\
\text { Within R-squared }=0.055374\end{array}$} \\
\hline
\end{tabular}

Note: ${ }^{* * *}$ statistically significant at a level of $0.01 ;{ }^{* *}$ statistically significant at a level of 0.05 ; *statistically significant at a level of 0.1 . 


\section{Tab. 8: Panel regression with random effects: ICT vs. the financial sector}

\begin{tabular}{|c|c|c|c|c|c|c|c|c|}
\hline \multirow{2}{*}{ Variable } & \multicolumn{4}{|c|}{ ICT } & \multicolumn{4}{|c|}{ Financial sector } \\
\hline & Coefficient & Std. error & Z & P-value & Coefficient & Std. error & Z & P-value \\
\hline Constant & -0.006715 & 0.009488 & -0.7077 & 0.4791 & 0.059603 & 0.065457 & 0.9106 & 0.3625 \\
\hline $\mathrm{ROA}$ & 0.003760 & 0.001538 & 2.444 & $0.0145^{\star *}$ & 0.006330 & 0.018923 & 0.3345 & 0.7380 \\
\hline IA & -0.049907 & 0.011895 & -4.196 & $2.72 \mathrm{e}^{-5 * * *}$ & -0.350310 & 0.519536 & -0.6743 & 0.5001 \\
\hline SIZE & 0.0029572 & 0.000979 & 3.020 & $0.0025^{\star * *}$ & 0.000459 & 0.004722 & 0.09714 & 0.9226 \\
\hline INDEBT & -0.001740 & 0.001398 & -1.244 & 0.2135 & -0.008738 & 0.012298 & -0.7105 & 0.4774 \\
\hline INV & 0.000101 & 0.014044 & 0.0072 & 0.9943 & 0.806338 & 8.46481 & 0.09526 & 0.9241 \\
\hline $\mathrm{TH}$ & -0.001130 & 0.005582 & -0.2025 & 0.8395 & -0.037433 & 0.025247 & -1.483 & 0.1382 \\
\hline Time $d_{.3}$ & 0.002498 & 0.002321 & 1.077 & 0.2817 & 0.003882 & 0.012070 & 0.3216 & 0.7478 \\
\hline Time $\mathrm{d}_{2}$ & 0.000982 & 0.002331 & 0.4212 & 0.6736 & 0.011480 & 0.012156 & 0.9444 & 0.3450 \\
\hline \multirow[t]{2}{*}{ Time $\mathrm{d}_{4}$} & 0.000289 & 0.002359 & 0.1224 & 0.9026 & 0.025050 & 0.012202 & 2.053 & $0.0401^{* \prime}$ \\
\hline & & & & & \multicolumn{4}{|c|}{$\begin{array}{l}\text { Wald joint test on time dummies }- \\
\text { Chi-squared }(3)=4.88547 \text { with } p \text {-value }=0.180378\end{array}$} \\
\hline
\end{tabular}

Source: own

Note: ***statistically significant at a level of 0.01 ; ${ }^{* *}$ statistically significant at a level of 0.05 ; *statistically significant at a level of 0.1 .

Shackelford, 2014; Davies et al., 2018). Regarding Czech companies, the situation is not as clear. Current studies show that there are probably differences between tax havens (Janský \& Kokeš, 2015; Janský, 2017). Moreover they indicate that the principle of using tax havens covers more than just the tax issue - rather, financial secrecy is also important for Czech companies (Rohan \& Moravec, 2017). The impact a tax haven connection has on the tax burden seems to be not as strong as in other countries. However, this situation has an empirical explanation. There are studies showing that profit shifting is not just for purposes of tax avoidance but that it is generally common to show preference for the parent company (Dischinger et al., 2014). Profit shifting is present even when there is no tax haven connection. Dischinger et al. (2014) show that profits are shifted based on the tax differential but that managers prefer to shift profits to parent companies if the tax rate is similar. Because this study is focused on companies that are subsidiaries of foreign parent companies, the model's results - taking into account the current research - show that profit shifting is linked to the majority of foreign subsidiaries. These profits are shifted to the parent companies no matter where they are located.
Unlike the papers by Janský and Kokeš (2015) or Ištok and Kanderová (2019), this study does not confirm the importance of a company's indebtedness as it relates to international tax planning. Because similar data samples have produced different results, it would be appropriate to conduct further research on this variable. In particular, companies from the financial sector are proposed for further study, because it can be expected that this sector uses intra-group loans.

Intangible assets are definitely used for tax avoidance; this study proves their use within the ICT sector. Companies with a higher percentage of intangible assets are linked to a lower tax burden. This is in line with previous studies that demonstrate the important role intangible assets play in tax avoidance (Griffith et al., 2014; Arcalean, 2017; Klassen et al., 2017). When a company has intangible assets, it can benefit more from tax avoidance, because intangible assets provide managers with more tax planning options to choose from.

Concerning the other determinants, company size was shown to be a variable with a positive impact on tax burden. It can be stated that companies with more assets pay higher taxes. The reasons why smaller companies have a lower tax burden cannot be determined 
from the results. When this result is placed in the context of previous studies, the situation becomes clear. Nowadays, there are many examples of media publicity for large groups and their tax planning activities (Campbell \& Helleloid, 2016; European Commission, 2020). Larger companies have to take better care of their reputation and often employ a policy called corporate social responsibility - tax avoidance is not in line with this attitude (Gribnau, 2015). On the other hand, Czech companies do not emphasize their fair tax payments (Svoboda, 2016).

The last important independent variable (the ICT sector dummy variable) opens the discussion about sectors, because companies from the ICT sector have a lower tax burden than companies from the financial sector. Their type of activity is completely different; moreover, their flexible organizational structure and new types of company management offer better opportunities for employing tax planning. This type of reasoning was also mentioned in Higgins et al. (2015) and Jones and Temouri (2016). From the perspective of governments and international organizations, the tendency is to apply special taxation regimes to ICT companies.

When it comes to comparing the studied sectors, it is obvious that the model is only relevant for the ICT sector. No dependency was revealed when the companies from the financial sector were assessed - except for one; the time dummy variable for 2016 had a positive effect on the tax burden. Financial companies showed higher tax liabilities in 2016. This situation could have been caused by media publicity of the obligations linked to Country-by-Country Reporting and of studies connected to this (Aubry \& Dauphin, 2017; Janský, 2017). The financial sector has become one of the most studied from the view of tax planning; therefore, financial managers are more careful with their tax planning activities. When the p-values associated with the time dummy variables were compared, it could be seen that companies from the financial sector paid higher tax liabilities over time. On the other hand, the additional test for the time variables did not confirm any time effect (see Tab. 8). Because the other additional tests (see Tab. 6) favor regression with random effects, the explanation for dependence linked to the tax burden is different. As mentioned above, managers must pay attention to the public's view of their companies' activities. Dyreng et al. (2010) show that managers' personalities also have an impact on companies' tax planning structures. The role of the differences between managers is also the subject of studies by Francis et al. (2014) and Christensen et al. (2015), both of which achieved similar conclusions, i.e., that managers also influence tax planning activities. When combined with the preference of regression with random effects for the financial sector, this fact indicates that the role of managers within the financial sector is stronger than in the ICT sector. Because the ICT sector belongs to the high-tech industry, the propensity for tax planning is much greater. On the other hand, the traditional financial sector is accompanied by random effects, so managers become drivers for the tax planning attitude. The financial sector includes people with different approaches to risk. There are careful managers who especially take the public's view of its activities into account and hesitate to use tax planning schemes. As to the other managers, the economic benefits of tax planning outweigh the threat of a deteriorating reputation. Another limitation can be seen in shorter period because regressions do not reveal any longterm effect, especially connected with strategy of companies. On the other hand, longer period would mean smaller balanced panel in terms of number of companies.

There is also a limitation that goes hand in hand with one of the model's positive aspects (the unique view on operating subsidiaries owned from abroad). This model only focuses on the aspect of Czech companies that can be connected with tax planning activities. Based on this limitation, the model is not suitable for all Czech companies. Naturally, when evaluating tax planning, purely Czech companies are not a relevant part of the dataset. On the other hand, it is worth mentioning that tax planning can also be present in Czech companies that have subsidiaries in foreign countries. This implies that possible future research could focus on companies as parent companies within tax planning schemes. Subsequent to this research, it would be constructive to compare these two types of connections companies have to foreign countries. This opens the discussion about another important factor possibly affecting the tax burden that has not been addressed by current studies, 
position within a group. When companies linked to foreign countries are studied, the dataset contains differences between the subsidiaries' positions. Some companies are originally from the Czech Republic and have been bought by a foreign company, some of them have been established by a multinational, some may be directly owned by the parent company of an entire group, or the distance between the head of the group and operating company may be much greater. The last example would be suitable for demonstrating the impact on tax planning. When there are many channels within which tax planning can be applied, there are more possibilities to avoid paying taxes. Moreover, when tax planning activities can be equally distributed between all the channels, the effects of tax avoidance are more difficult to detect.

In light of this paper confirming significant differences between sectors, subjects of further research should not include only company managers and a company's position within a group. Researchers should take into account the differences between sectors and ideally study them individually. In view of the differences between sectors, the initiative of several countries (Asen, 2019) to introduce digital taxes makes sense. On the other hand, when companies from certain sectors face lower (or higher) taxation, it does not affect their competitive standing, because the situation within the sector is the same for all its members.

\section{Conclusions}

The model introduced here provides a new approach to international tax planning models, because its primary focus is the tax burden of subsidiaries. Naturally, when a multinational group applies tax planning, the tax burden of the whole group decreases. The question then arises of how this affects the tax burden of the operating subsidiary. Because a subsidiary can be part of a tax planning scheme, its tax burden can also be affected by tax avoidance. For these purposes, a new dependent variable was introduced: taxes divided by outcomes.

The model demonstrated different situations for the two sectors selected, ICT and financial sector. Both of these are described as sectors with a greater tendency to use tax havens. With regards to the fact that tax havens have no effect on tax burden, companies in these two sectors use profit shifting in the direction of the parent companies. Intangible assets are used for tax planning in the ICT sector; however, the tax burden of companies from the financial sector is influenced by random effects that are probably linked to managerial approach.

Further research on international tax planning should include not only information about sectors, but it is also necessary to approach each sector individually. It would be constructive for other experts to take into account alternative qualitative attributes affecting the tax burden. The current situation has brought about new types of taxation that are intended only for certain companies. Therefore, the differences between sectors will widen, but not from the perspective of the tax burden (sectoral taxation should help balance out the tax environment); rather, the determinants in similar models will begin to show even more variation across the sectors.

Acknowledgment: This paper was supported by the Student Grant Competition (grant No. 16) of University of Pardubice in 2020. I would like to thank Hana Kučerová for her help with the text editing.

\section{References}

Arcalean, C. (2017). International tax competition and the deficit bias. Economic Inquiry, 55(1), 51-72. https://doi.org/10.1111/ecin.12358

Asen, E. (2019). Announced, Proposed, and Implemented Digital Services Taxes in Europe. Retrieved February 13, 2020, from https:// taxfoundation.org/digital-taxes-europe-2019/

Aubry, M., \& Dauphin, T. (2017). Opening the Vaults: The use of tax havens by Europe's biggest banks. Oxfam International. Oxford: Oxfam GB. Retrieved from https://www.oxfam. org/en/research/opening-vaults

Auerbach, A. J., Devereux, M. P., Keen, M., \& Vella, J. (2017). International Tax Planning under the Destination-Based Cash Flow Tax. National Tax Journal, 70(4), 783-802. https:// doi.org/10.17310/ntj.2017.4.04

Berkhout, E. (2016). Tax Battles: The dangerous global race to the bottom on corporate tax. Oxfam International. Oxford: Oxfam GB. Retrieved from https://www.oxfam. org/en/research/tax-battles-dangerous-globalrace-bottom-corporate-tax

Buettner, T., \& Wamser, G. (2013). Internal Debt and Multinational Profit Shifting: Empirical Evidence from Firm-level Panel Data. 
National Tax Journal, 66(1), 63-96. https://doi. org/10.17310/ntj.2013.1.03

Bouvatier, V., Capelle-Blancard, G., \& Delatte, A. L. (2017). Banks in Tax Havens: First Evidence based on Country-by-Country Reporting. Luxembourg: Publications Office of the European Union.

Campbell, K., \& Helleloid, D. (2016). Starbucks: Social responsibility and tax avoidance. Journal of Accounting Education, 37, 38-60. https://doi.org/10.1016/j. jaccedu.2016.09.001

Chardonnet, A., \& Langerock, J. (2017). Blacklist or whitewash? What a real EU blacklist of tax havens should look like. Oxfam International. Oxford: Oxfam GB. Retrieved from https://www.oxfam.org/en/research/ blacklist-or-whitewash-what-real-eu-blacklisttax-havens-should-look

Christensen, D. M., Dhaliwal, D. S., Boivie, S., \& Graffin, S. D. (2015). Top management conservatism and corporate risk strategies: Evidence from managers' personal political orientation and corporate tax avoidance. Strategic Management Journal, 36(12), 19181938. https://doi.org/10.1002/smj.2313

Davies, R. B., Martin, J., Parenti, M., \& Toubal, F. (2018). Knocking Tax Haven's Door: Multinational Firms and Transfer Pricing. Review of Economics and Statistics, 100(1), 120-134. https://doi.org/10.1162/REST_a_00673

Delgado, F. J., Fernandez-Rodriguez, E., \& Martinez-Arias, A. (2014). Effective Tax Rates in Corporate Taxation: A Quantile Regression for the EU. Inzinerine Ekonomika - Engineering Economics, 25(5), 487-496. https://doi. org/10.5755/j01.ee.25.5.4531

Desai, M. A., Foley, C. F., \& Hines Jr, J. R. (2006). The demand for tax haven operations. Journal of Public Economics, 90(3), 513-531. https://doi.org/10.1016/j.jpubeco.2005.04.004

Dischinger, M., Knoll, B., \& Riedel, N. (2014). The role of headquarters in multinational profit shifting strategies. International Tax and Public Finance, 21(2), 248-271. https://doi. org/10.1007/s10797-012-9265-5

Dyreng, S. D., \& Lindsey, B. P. (2009). Using Financial Accounting Data to Examine the Effect of Foreign Operations Located in Tax Havens and Other Countries on U.S. Multinational Firms' Tax Rates. Journal of Accounting Research, 47(5), 1283-1316. https://doi. org/10.1111/j.1475-679X.2009.00346.x
Dyreng, S. D., Hanlon, M., \& Maydew, E. L. (2010). The effects of executives on corporate tax avoidance. The Accounting Review, 85(4), 1163-1189. https://doi.org/10.2308/ accr.2010.85.4.1163

European Commission. (2016). Study on Structures of Aggressive Tax Planning and Indicators (Taxation Paper No. 61). Luxembourg: Office for Official Publications of the European Communities. Retrieved February 21, 2020, from https://ec.europa.eu/taxation_customs/sites/ taxation/files/resources/documents/taxation/gen info/economic_analysis/tax_papers/taxation_ paper_61.pdf https://doi.org/10.2778/59284

European Commission. (2017). A Fair and Efficient Tax System in the European Union for the Digital Single Market (Communication No. 547 from the Commission to the European Parliament and the Council). Brussels: European Commission. Retrieved from https:// ec.europa.eu/taxation_customs/sites/taxation/ files/communication_taxation_digital_single_ market_en.pdf

European Commission. (2018a). Evolution of the EU list of tax havens. Brussels: European Commission. Retrieved February 24, 2020, from https://ec.europa.eu/taxation_customs/sites/ taxation/files/eu_list_update_25_05_2018_en.pdf

European Commission. (2018b). Fair Taxation of the Digital Economy. Brussels: European Commission. Retrieved February 13, 2020, from https://ec.europa.eu/taxation_customs/business/ company-tax/fair-taxation-digital-economy_en

European Commission. (2020). Competition. State aid. Tax rulings. Brussels: European Commission. Retrieved February 24, 2020, from http://ec.europa.eu/competition/ state_aid/tax_rulings/index_en.html

Evers, L., Miller, H., \& Spengel, C. (2015). Intellectual property box regimes: effective tax rates and tax policy considerations. International Tax and Public Finance, 22(3), 502-530. https://doi.org/10.1007/s10797-014-9328-x

Francis, B. B., Hasan, I., Wu, Q., \& Yan, M. (2014). Are female CFOs less tax aggressive? Evidence from tax aggressiveness. The Journal of the American Taxation Association, 36(2), 171-202. https://doi.org/10.2308/atax-50819

Gallemore, J., Gipper, B., \& Maydew, E. (2019). Banks as Tax Planning Intermediaries. Journal of Accounting Research, 57(1), 169209. https://doi.org/10.1111/1475-679X.12246

Graham, J. R., Hanlon, M., Shevlin, T., \& Shroff, N. (2014). Incentives for Tax Planning 
and Avoidance: Evidence from the Field. The Accounting Review, 89(3), 991-1023. https://doi.org/10.2308/accr-50678

Gravelle, J. G. (2015). Tax Havens: International Tax Avoidance and Evasion (CRS Report No. R40623). Washington, DC: Congressional Research Service. Retrieved from https://www.fas.org/sgp/crs/misc/R40623.pdf

Greene, W. H. (2012). Econometric Analysis. Harlow: Pearson Education Limited.

Gribnau, H. (2015). Corporate Social Responsibility and Tax Planning: Not by Rules Alone. Social \& Legal Studies, 24(2), 225-250. https://doi.org/10.1177/0964663915575053

Griffith, R., Miller, H., \& O'Connell, M. (2014). Ownership of intellectual property and corporate taxation. Journal of Public Economics, 112, 12-23. https://doi.org/10.1016/j. jpubeco.2014.01.009

Gumpert, A., Hines Jr., J. R., \& Schnitzer, M. (2016). Multinational Firms and Tax Havens. Review of Economics and Statistics, 98(4), 713727. https://doi.org/10.1162/REST_a_00591

Heckemeyer, J. H., \& Overesch, M. (2017). Multinationals' profit response to tax differentials: Effect size and shifting channels. Canadian Journal of Economics/Revue canadienne d'économique, 50(4), 965-994. https://doi.org/10.1111/caje.12283

Higgins, D., Omer, T. C., \& Phillips, J. D. (2015). The Influence of a Firm's Business Strategy on its Tax Aggressiveness. Contemporary Accounting Research, 32(2), 674-702. https://doi.org/10.1111/1911-3846.12087

Hong, Q., \& Smart, M. (2010). In praise of tax havens: International tax planning and foreign direct investment. European Economic Review, 54(1), 82-95. https://doi.org/10.1016/j. euroecorev.2009.06.006

Ištok, M., \& Kanderová, M. (2019). Debt/ asset ratio as evidence of profit-shifting behaviour in the Slovak Republic. Technological and Economic Development of Economy, 25(6), 1293-1308. https://doi.org/10.3846/ tede.2019.11338

Janský, P. (2017). Country-by-country reporting data of banks: tax havens and the Czech Republic. Prague: Glopolis. Retrieved February 13, 2020, from http://glopolis.org/wpcontent/uploads/Country-by-country-reportingdata-of-banks-tax-havens-and-the-CzechRepublic.pdf

Janský, P., \& Kokeš, O. (2015). Corporate tax base erosion and profit shifting out of the
Czech Republic. Post-Communist Economies, 27(4), 537-546. https://doi.org/10.1080/146313 77.2015 .1084733

Janský, P., \& Kokeš, O. (2016). Profitshifting from Czech multinational companies to European tax havens. Applied Economics Letters, 23(16), 1130-1133. https://doi.org/10.1 080/13504851.2015.1137543

Jedlička, V. (2019). International Aspects of Business' Tax Planning (Doctoral dissertation). Pardubice: Printing Centre of the University of Pardubice.

Jones, C., \& Temouri, Y. (2016). The determinants of tax haven FDI. Journal of world Business, 51(2), 237-250. https://doi. org/10.1016/j.jwb.2015.09.001

Justice.cz. (2018). Justice.cz. Retrieved July 18, 2018, from https://www.justice.cz/

Karkinsky, T., \& Riedel, N. (2012). Corporate taxation and the choice of patent location within multinational firms. Journal of International Economics, 88(1), 176-185. https://doi. org/10.1016/j.jinteco.2012.04.002

Klassen, K. J., Lisowsky, P., \& Mescall, D. (2017). Transfer Pricing: Strategies, Practices, and Tax Minimization. Contemporary Accounting Research, 34(1), 455-493. https://doi.org/10.1111/1911-3846.12239

Markle, K. S., \& Shackelford, D. A. (2014). The Impact of Headquarter and Subsidiary Locations on Multinationals' Effective Tax Rates. Tax Policy and the Economy, 28(1), 3362. https://doi.org/10.1086/675587

Moravec, L., Rohan, J., \& Hinke, J. (2019). Estimation of International Tax Planning Impact on Corporate Tax Gap in the Czech Republic. E\&M Economics and Management, 22(1), 157171. https://doi.org/10.15240/tul/001/2019-1-011

Murphy, R. (2015). European Banks' Country-by-Country Reporting. Retrieved from http://www.taxresearch.org.uk/Documents/ CRDivCBCR2015.pdf

OECD. (2020a). Glossary of Tax Terms. Retrieved February 21, 2020, from http://www. oecd.org/ctp/glossaryoftaxterms.htm

OECD. (2020b). Base erosion and profit shifting. Retrieved February 24, 2020, from http://www.oecd.org/tax/beps/

OECD. (2020c). List of Unco-operative Tax Havens. Retrieved February 24, 2020, from http://www.oecd.org/countries/liechtenstein/listof-unco-operative-tax-havens.htm

OECD. (2020d). Action 1 Tax Challenges Arising from Digitalisation. Retrieved February 
13, 2020, from https://www.oecd.org/tax/beps/ beps-actions/action1/

Rego, S. O. (2003). Tax-Avoidance Activities of U.S. Multinational Corporations. Contemporary Accounting Research, 20(4), 805-833. https://doi.org/10.1506/VANN-B7UBGMFA-9E6W

Rohan, J., \& Moravec, L. (2017). Tax Information Exchange Influence on Czech Based Companies' Behavior in Relation to Tax Havens. Acta Universitatis Agriculturae et Silviculturae Mendelianae Brunensis, 65(2), 721-726. https://doi.org/10.11118/ actaun201765020721

Schenkelberg, S. (2020). The Cadbury Schweppes judgment and its implications on profit shifting activities within Europe. International Tax and Public Finance, 27(1), 1-31. https://doi. org/10.1007/s10797-019-09553-w

Schulte, S. K., Thomsen, M., \& Watrin, C. (2017). Do European corporate groups with subsidiaries in tax havens avoid more taxes than others? SSRN Electronic Journal.
Sorbe, S., \& Johansson, Å. (2017). International tax planning and fixed investment (Economics Department Working Papers, No. 1361). Paris: OECD Publishing. https://doi. org/10.1787/83239540-en

Svoboda, P. (2016). Transparent corporate tax paid by companies in the Czech Republic as tool in their public relations. Scientific Papers of the University of Pardubice, Series D, Faculty of Economics and Administration, 24(3), 168-176.

Wiebe, T. (2011). The Benefits of Tax Competition. Retrieved February 13, 2020, from https://taxfoundation.org/benefits-taxcompetition/

Wooldridge, J. M. (2013). Introductory Econometrics: A Modern Approach. Mason, $\mathrm{OH}$ : South-Western Cengage Learning.

Yoo, J. S., \& Lee, Y. J. (2019). National Culture and Tax Avoidance of Multinational Corporations. Sustainability, 11(24), 6946. https://doi.org/10.3390/su11246946 